\title{
VPLIV UČINKA POZNANSTVA IN SOSEDSTVA NA VOLILNO VEDENJE V VOLILNEM OKRAJU TOLMIN
}

\author{
Alen Červ, dipl. geograf \\ Šavlijeva ulica 4, SI-5220 Tolmin \\ e-mail:Alen.cherv@hotmail.com \\ Izvirni znanstveni članek \\ COBISS 1.01 \\ DOI: $10.4312 /$ dela.44.2.25-43
}

\section{Izvleček}

Članek analizira vpliv učinka poznanstva in sosedstva na volilno vedenje na primeru volilnega okraja Tolmin. S statističnimi in kartografskimi analizami rezultatov državnozborskih volitev iz let 2008 in 2011 smo prikazali rezultate dvanajstih kandidatov. Potrjenih je bilo več primerov šibkega oziroma zmernega vpliva preučevanega učinka na volilno vedenje, prostorska razporeditev podpore kandidatom pa je odsevala razlike med mestnimi in podeželskimi območji ter vpliv lokalnih posebnosti (medsosedsko rivalstvo, gravitacijska zaledja, funkcije kandidatov) na volilno vedenje.

Ključne besede: politična geografija, geografija volitev, volitve, volilno vedenje, učinek poznanstva in sosedstva, Tolmin, Slovenija

\section{THE IMPACT OF FRIENDS-AND-NEIGHBOURS EFFECT ON ELECTORAL BEHAVIOUR IN THE TOLMIN ELECTORAL DISTRICT}

\begin{abstract}
This paper discusses the impact of friends-and-neighbours effect on results of Slovenian parliamentary elections in 2008 and 2011. Its impact on electoral behaviour has been verified by statistical and cartographic analyses of election results in the Tolmin electoral district. Some cases with weak or moderate impact of analysed phenomena were proven, while spatial distribution of candidates support signalled the differences between urban and rural areas and impact of local specifics (neighbourhood rivalry, gravitation hinterland, career position of candidates) on electoral behaviour.
\end{abstract}

Key words: political geography, electoral geography, elections, electoral behaviour, friends-and-neighbours effect, Tolmin, Slovenia 


\section{UVOD}

Volilna pravica, s katero lahko ljudstvo namesti ali odstrani vladajočo strukturo v parlamentu, je najbolj temeljna med pravicami državljana (Jones, Woods, 2004). Ljudstvo izraža svojo voljo na periodično izvedenih volitvah. V prispevku je pozornost namenjena slovenskim državnozborskim volitvam, ki hkrati služijo kot zgled pri določanju volilnega sistema volitev na regionalni in lokalni ravni. 90 poslanskih mest v Državnem zboru Republike Slovenije se deli po proporcionalnem volilnem sistemu, ki za razliko od večinskega omogoča uspeh večjemu številu političnih strank. Te na volitvah nastopajo z lokalnimi kandidati, ki so razporejeni med 88 volilnih okrajev; toliko je tudi predvidenih poslanskih mest, saj sta preostala dva mandata rezervirana za predstavnika narodnih manjšin (ZVDZ, 1992; Rogelj, 2012).

Podrobnejši vpogled v slovenski volilni sistem razkriva specifičen paradoks. Prebivalstvo voli lokalne kandidate, njihov glas pa prvenstveno služi razdelitvi mandatov med politične stranke in zagotavlja le posredno podporo izbranemu kandidatu, ki mora za preboj v parlament zabeležiti dovolj dober rezultat v internem boju s preostalimi kandidati svoje stranke (ZVDZ, 2006; Rogelj, 2012). Ker tovrsten volilni sistem postavlja v ospredje boj med strankami in potiska izbiro posameznih lokalnih kandidatov v drugi plan, je pričakovati, da bo vodilni kriterij odločanja volilnega telesa temeljil na simpatiziranju s strankarskimi programi.

Vendar na volilno vedenje vpliva širok spekter dejavnikov, zaradi katerih lahko rezultati volitev močno odstopajo od pričakovanj. To dokazujeta tudi primera slovenskih državnozborskih volitev leta 2011 in leta 2014, ko sta najboljši rezultat zabeležili stranki, ki sta bili ustanovljeni le nekaj mesecev pred volitvami. Ker je Slovenija sorazmerno majhna država, je mogoče pričakovati večji vpliv lokalnih posebnosti na volilno vedenje.

Prispevek analizira pojav, ki se v angleški strokovni literaturi označuje s terminom friends-and-neighbours effect in se opredeljuje kot težnja volilnega telesa, da svoj glas dodeli kandidatu, ki prihaja z domačega območja (Simiyu, 2010). Opisani pojav v slovenskem kontekstu še ni bil podrobneje raziskan; interpretira se lahko kot učinek poznanstva in sosedstva.

Raziskava obsega kvantitativno in prostorsko analizo rezultatov državnozborskih volitev v letih 2008 in 2011. Ugotavljali smo jakost vpliva učinka poznanstva in sosedstva na volilno vedenje v tolminskem volilnem okraju, ki vključuje občine Tolmin, Kobarid in Bovec. Delo je obsegalo pregled literature o učinku poznanstva in sosedstva, pripravo in urejanje rezultatov volitev, pripravo prostorskih podatkov o voliščih in njihovi medsebojni oddaljenosti, statistično analizo podatkov in kartografski prikaz razporeditve podpore posameznim kandidatom.

V ospredju raziskave so bila tri tematska žarišča:

- merjenje prisotnosti pojava učinka poznanstva in sosedstva ter vrednotenje njegovega vpliva na volilno vedenje;

- primerjava intenzitete pojava med kandidati glede na njihov izvor (mesto ali podeželje);

- vzroki, ki vplivajo na specifično prostorsko razporeditev podpore posameznim kandidatom. 


\section{UČINEK POZNANSTVA IN SOSEDSTVA}

Na volilno vedenje vpliva širok spekter dejavnikov, ki jih Pečjak (1995, str. 180) v grobem deli na štiri skupine. Najpomembnejšo vlogo namenja societalnim dejavnikom, kamor spadajo verska, etnična in rasna pripadnost, spol, starost in poklic volivca. Globalizacija, urbanizacija in splošno širjenje obzorij pri percepciji okolice postopoma zmanjšujejo pomen teh dejavnikov, na pomembnosti pa pridobivajo propagandni in osebnostni dejavniki. Prvi izhajajo iz volilne kampanje, ki ima največji vpliv na neodločen del volilnega telesa, medtem ko osebnostni dejavniki temeljijo na osebnostnih značilnostih posameznih kandidatov, ki niso nujno povezani s programom njihovih strank. Zadnja skupina predstavlja sistemske dejavnike, ki so bolj tehnične narave in obsegajo omejevanje volilne pravice, trajanje kampanje in druge značilnosti volilnega postopka.

Nekateri avtorji (Luthar, 1993; Simiyu, 2010; Tiran, 2010) izpostavljajo še dve skupini dejavnikov: sociološke in geografske. Prvi izražajo pomen položaja posameznika v družbi, njegovih vsakodnevnih stikov z okolico, položaja na delu in življenjskega stila pri oblikovanju volilnega vedenja. Drugi izhajajo iz značilnosti prostora, ki nikakor ni le podlaga družbenim procesom, pač pa je s povratnimi reakcijami njihov aktivni del. Primer geografskega dejavnika je učinek soseščine (ang. neighbourhood effect), ki se kaže v prilagajanju posameznika težnjam okolice ne glede na njegov osebni položaj. S prostorskimi podatki je mogoče pojasniti tudi učinek poznanstva in sosedstva, ki se kaže v korelaciji med višanjem podpore kandidatu s približevanjem njegovemu domačemu volišču.

Učinek poznanstva in sosedstva se odraža v podpori kandidatom z domačega območja in to ne glede na njihovo strankarsko pripadnost. Pri pojasnjevanju tega pojava izhajamo iz predpostavke, da fizična bližina predstavlja podlago za razvoj socialne bližine. Volivci bolje poznajo domače kandidate, jim pripisujejo večjo dovzetnost za lokalno problematiko ter z njimi delijo podobne interese (Simiyu, 2010). Kandidatom zaupajo, da se bodo na državni ravni zavzeli za odločitve, ki bodo neposredno koristile tudi njim. Poleg občutka volivcev, da bodo z izvolitvijo 'domačega' kandidata dejansko nekaj pridobili tudi sami, lahko razlogi za odklon od pričakovanega volilnega vedenja izhajajo tudi iz težav 'nedomačih' kandidatov. Poleg nepoznavanja lokalnih problematik imajo lahko težave že z izgovorjavo krajevnih imen, uporabo tujega narečja ali zaradi priimka, ki nakazuje na tuj izvor (Gimpel, 2008).

Osebno poznavanje velja za enega pomembnejših vzrokov podpiranja domačih kandidatov. Gre predvsem za poznavanje osebnosti in kvalitet kandidata, ki s tem postane bolj 'človeški' od ostalih imen na glasovnici. Poleg tega se pri volivcih ustvari notranji občutek dolžnosti, da podprejo kandidata, s katerim so v vsakodnevnih stikih (Johnston, 1974; Taylor, Johnston, 1979).

Še pomembnejši dejavnik je zaupanje v kandidata. Prav vsakodnevni stiki dajejo volilnemu telesu nekakšno zagotovilo, da bo njihov izbranec moral za svoja dejanja osebno odgovarjati, kar vzbuja veliko višjo mero zaupanja v primerjavi s kandidati, ki jih volivci ne poznajo. Poznanih je tudi več podrobnosti iz kandidatovega preteklega udejstvovanja, nekateri volivci pa so morda $\mathrm{z}$ njim v preteklosti že sodelovali, zato mu pripisujejo večjo kredibilnost. 
Upoštevati je potrebno tudi osebni interes volivcev. Ti razmišljajo potrošniško in vsako svojo odločitev pogojujejo z lastno koristjo. Bolj kot preučevanje obče kakovosti programa stranke se jim poraja vprašanje, kaj bodo sami pridobili v primeru zmage znanega kandidata. Od lokalnega kandidata se zato pričakuje, da bo poskrbel za probleme v domačem okolju, čeprav to morda ni del programa njegove stranke (Gimpel, 2008).

Takšnemu načinu razmišljanja se vsaj nekoliko prilagaja tudi volilna kampanja strank, ki spretno izkorišča lokalne interese in se med posameznimi lokalnimi kandidati razlikuje; v odnosu do lokalnih problemov včasih celo nasprotuje svojim osnovnim programskim načelom. S tovrstnim promoviranjem poznavanja in skrbi za lokalne interese se možnost učinka poznanstva in sosedstva znatno poveča (Johnston, 1974; Key, 1949).

Nenazadnje je pomembna tudi politična situacija $v$ državi. Podpora domačim kandidatom izhaja iz pomanjkanja stabilnih in dobro organiziranih političnih frakcij podobno mislečih državljanov, ki bi na državni ravni zastopali in zagovarjali ukrepe v skupnem interesu (Key, 1949). Takšna situacija vzbuja neodločnost in skrb za lasten interes. Prav tako lahko vzrok iščemo v neizraziti strankarski delitvi. Če je na političnem prizorišču večje število strank, med programi pa je težko potegniti jasne ločnice, je verjetnost učinka poznanstva in sosedstva veliko večja kot pri izrazito bipolarni politični delitvi, kjer igra strankarska pripadnost odločilno vlogo pri odločanju.

Med izrazito geografskimi vzroki velja izpostaviti še tip naselja. V urbaniziranih okoljih se prebivalci med seboj slabo ali sploh ne poznajo, niti ni prisotne medsebojne povezanosti in podpiranja pri udejstvovanju. Velikokrat se tudi zgodi, da je med kandidati več prebivalcev istega mestnega okolja, kar pomen poznanstva in sosedstva dodatno zmanjšuje. Na drugi strani je socialna homogenost obrobnih območij veliko večja, ljudje se med seboj dobro poznajo in so si navajeni pomagati. Posamezna podeželska naselja se sicer redkeje srečujejo s priložnostjo, da imajo na volitvah domačega predstavnika, ko pa se to vendarle zgodi, praviloma podprejo domačina (Gimpel, 2008).

\section{METODE}

Učinek poznanstva in sosedstva se statistično kaže v negativni korelaciji med deležem prejete podpore na posameznem volišču in njegovo oddaljenostjo od kandidatovega domačega volišča. Analiza temelji na rezultatih državnozborskih volitev iz let 2008 in 2011 po voliščih v volilnem okraju (VO) Tolmin ter podatkih o stalnem bivališču kandidatov. Omenjene podatke smo pridobili na spletni strani Državne volilne komisije (DVK-RS, 2013). Volišča so najmanjša administrativna prostorska enota, za katero se zbirajo podatki o volilnih rezultatih.

VO Tolmin smo za preučevanje izbrali, ker z obrobno lego ustreza predpostavki o favoriziranju lokalnih kandidatov zaradi strahu pred zapostavljenostjo (Červ, 2014). Redka poselitev in socialna homogenost območja bi morali botrovati tesnejšim vezem in boljšemu medsebojnemu poznavanju lokalnega prebivalstva, kar po dosedanjih raziskavah povečuje vpliv učinka poznanstva in sosedstva (Gimpel, 2008; Taylor, Johnston, 1979). Relativno majhno in funkcijsko zaokroženo območje je omogočalo natančnejšo analizo volilnih rezultatov posameznih kandidatov. 
Domače volišče kandidata je izhodiščna točka za analizo učinka poznanstva in sosedstva. Določal ga je naslov stalnega bivališča kandidatov, kar sicer zanemarja nekatere dejavnike, kot so npr. čas bivanja, kraj bivanja kandidatovih sorodnikov, kraj zaposlitve itd. Kljub temu ocenjujemo, da gre za metodološko najboljšo možno rešitev, ki jo dostopni podatki še omogočajo. Pri kandidatih s stalnim bivališčem v mestih, ki so razdeljena na več volišč, smo volišča za potrebe analize združili, saj so naselja Tolmin, Kobarid in Bovec po številu prebivalcev in prostorsko premajhna, da bi lahko pričakovali razlike v volilnem vedenju med posameznimi mestnimi četrtmi.

\section{Slika 1: Volilni okraj Tolmin}

Figure 1: Tolmin electoral district

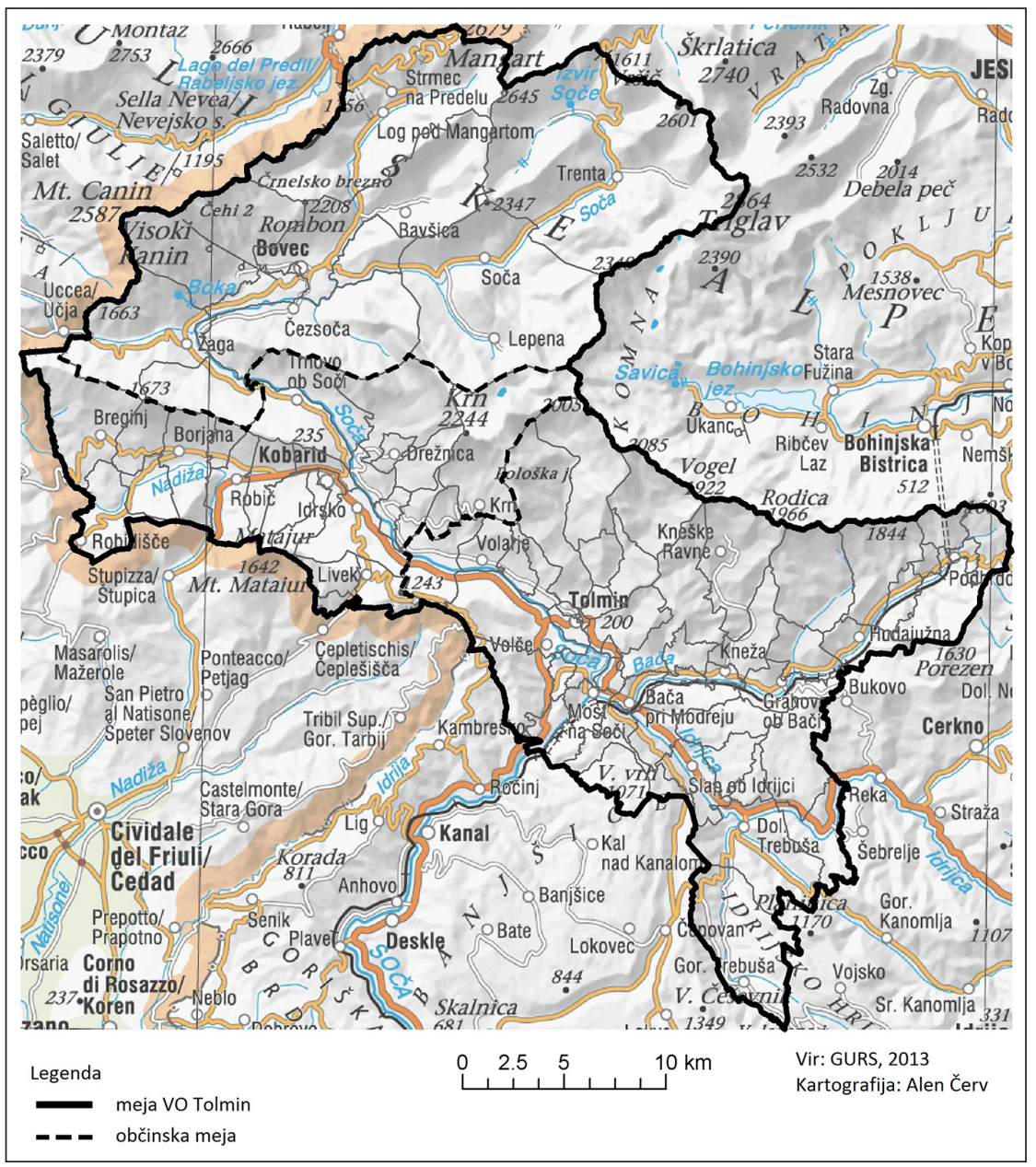

Vir/Source: GURS, 2013b 
$\mathrm{V}$ analizo smo vključili le kandidate parlamentarnih strank. S tem smo se v veliki meri izognili primerom premajhnega deleža prejete podpore, ki bi vplivali na statistično pomembnost končnih rezultatov. Na obeh volitvah se je v Državni zbor uspelo prebiti sedmim strankam. Ker so bili iz analize izključeni tudi kandidati s stalnim bivališčem izven preučevanega VO, je za statistično in kartografsko analizo prostorske razporeditve prejete podpore ostalo dvanajst primerov.

Preglednica 1: Rezultati parlamentarnih volitev v Sloveniji iz let 2008 in 2011

Table 1: Results of Slovenian parliamentary elections in 2008 and 2011

\begin{tabular}{|c|c|c|c|c|c|c|}
\hline \multicolumn{7}{|c|}{ Rezultati parlamentarnih volitev 2008} \\
\hline \multirow{2}{*}{$\begin{array}{l}\text { Kandidatna } \\
\text { lista }\end{array}$} & \multirow{2}{*}{$\begin{array}{c}\text { Št. glasov } \\
\text { (Slovenija) }\end{array}$} & \multicolumn{5}{|c|}{ Delež glasov $(\%)$} \\
\hline & & Slovenija & VO Tolmin & $\begin{array}{l}\text { Občina } \\
\text { Tolmin }\end{array}$ & $\begin{array}{c}\text { Občina } \\
\text { Kobarid }\end{array}$ & $\begin{array}{c}\text { Občina } \\
\text { Bovec }\end{array}$ \\
\hline SD & 320.248 & 30,45 & 23,99 & 24,80 & 18,52 & 26,09 \\
\hline SDS & 307.735 & 29,26 & 38,40 & 32,50 & 51,24 & 44,15 \\
\hline Zares & 98.526 & 9,37 & 5,55 & 5,20 & 5,83 & 5,82 \\
\hline DeSUS & 78.353 & 7,45 & 9,01 & 9,04 & 7,38 & 11,76 \\
\hline SNS & 56.832 & 5,40 & 3,92 & 4,20 & 4,35 & 3,00 \\
\hline SLS & 54.809 & 5,21 & 9,08 & 13,62 & 3,23 & 2,28 \\
\hline LDS & 54.771 & 5,21 & 2,47 & 2,38 & 2,51 & 2,28 \\
\hline \multicolumn{7}{|c|}{ Rezultati parlamentarnih volitev 2011} \\
\hline \multirow[b]{2}{*}{$\begin{array}{l}\text { Kandidatna } \\
\text { lista }\end{array}$} & \multirow{2}{*}{$\begin{array}{r}\text { Št. glasov } \\
\text { (Slovenija) }\end{array}$} & \multicolumn{5}{|c|}{ Delež glasov (\%) } \\
\hline & & Slovenija & VO Tolmin & $\begin{array}{l}\text { Občina } \\
\text { Tolmin }\end{array}$ & $\begin{array}{c}\text { Občina } \\
\text { Kobarid }\end{array}$ & $\begin{array}{c}\text { Občina } \\
\text { Bovec }\end{array}$ \\
\hline PS & 314.273 & 28,51 & 17,58 & 18,50 & 15,84 & 18,12 \\
\hline SDS & 288.719 & 26,19 & 31,99 & 27,76 & 43,36 & 36,97 \\
\hline SD & 115.952 & 10,52 & 10,47 & 11,66 & 6,75 & 10,73 \\
\hline DLGV & 92.282 & 8,37 & 8,39 & 9,18 & 6,28 & 9,39 \\
\hline DeSUS & 76.853 & 6,97 & 6,62 & 7,21 & 5,57 & 6,61 \\
\hline SLS & 75.311 & 6,83 & 6,35 & 7,77 & 5,06 & 4,30 \\
\hline $\mathrm{NSi}$ & 53.758 & 4,88 & 6,65 & 6,87 & 8,29 & 3,52 \\
\hline
\end{tabular}

Vir/Source: DVK-RS, 2013

Analiza rezultatov je razdeljena na tri sklope. V prvem delu je VO Tolmin razdeljen na mestna in podeželska območja. Primarna delitev izhaja iz upravne delitve na občine. Posamezna volišča znotraj mest smo združili, podeželsko okolico pa razdelili glede na gravitacijska središča, naravnogeografske značilnosti in upravno delitev na šolske okoliše. Tako smo pridobili vmesno prostorsko enoto med VO in posameznimi volišči (slika 2). Za začetno oceno smiselnosti nadaljnje raziskave smo opravili primerjavo podpore kandidatu na njegovem domačem volišču, na domačem mestnem/podeželskem območju in na celotnem območju VO. Hkrati smo ugotavljali tudi razlike v vplivu učinka poznanstva in sosedstva med rezultati kandidatov iz mestnih območij in tistih s stalnim prebivališčem na podeželju. 
Slika 2: Delitev tolminskega volilnega okraja na mestna in podeželska območja Figure 2: Division of the Tolmin electoral district into urban and rural areas

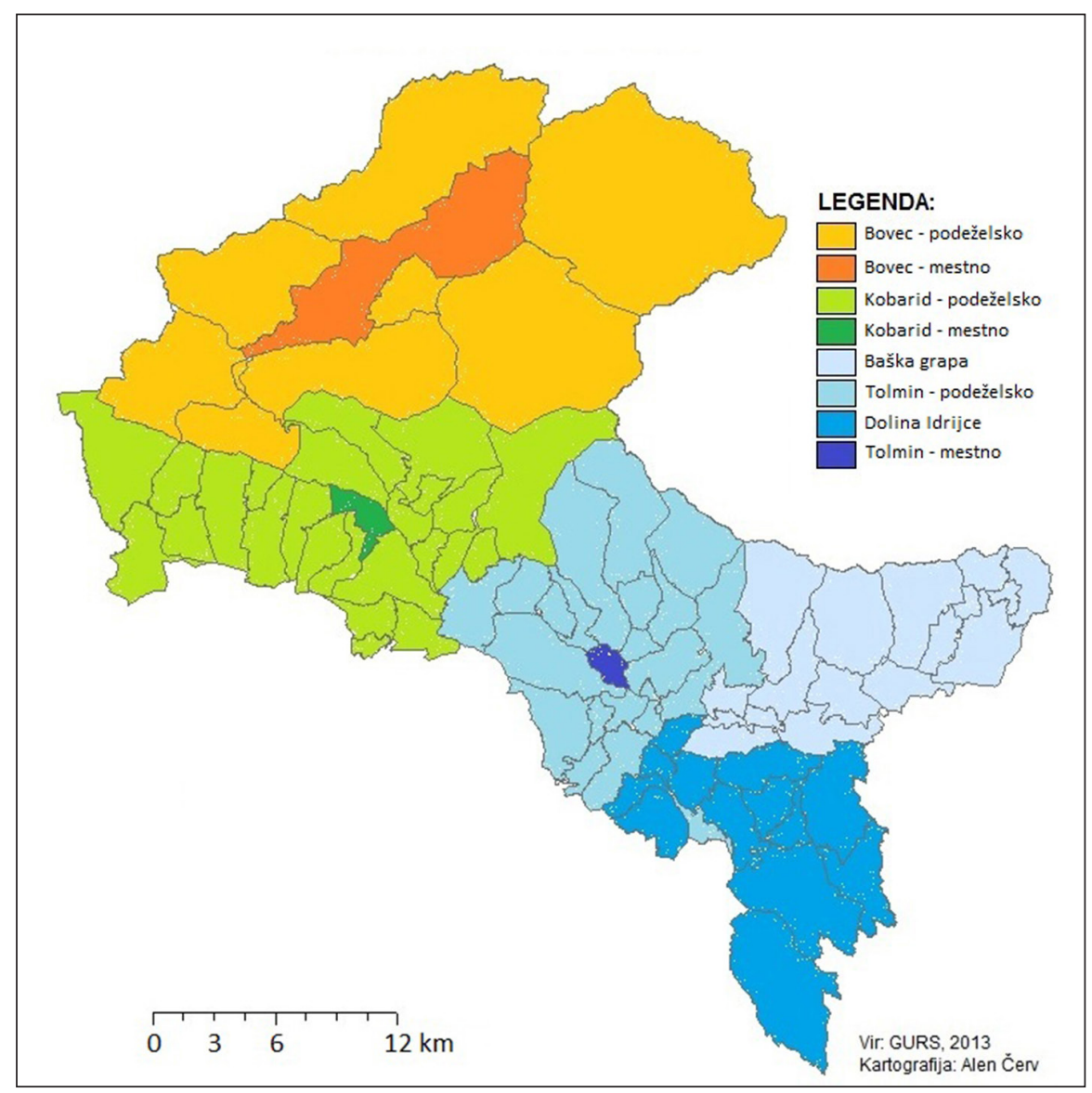

Vir/Source: GURS, $2013 b$

V drugem delu smo se osredotočili na natančno statistično analizo korelacije med deležem prejete podpore in oddaljenostjo od domačega volišča. Rezultatom volitev je bilo potrebno dodati še prostorsko komponento. S pomočjo programske opreme ArcGIS smo vsakemu volišču določili geometrično središče in izračunali evklidsko razdaljo do vseh ostalih volišč. Postopek ni najbolj natančen, vendar v večini primerov zagotavlja normalno porazdelitev spremenljivke, kar je pogoj za izvajanje statističnih analiz. Zaradi večje reprezentativnosti rezultatov smo uporabili še drugo metodo izračuna razdalje. S pomočjo katastra stavb (GURS, 2013c) smo določili središča volišč glede na največjo gostoto stavb, ki na pretežno podeželskih območjih, kot je primer Tolminskega, v glavnem nakazuje največjo gostoto poselitve. Tudi evklidsko razdaljo smo zamenjali s stroškovno, 
ki smo jo izračunali glede na premagane naklone (GURS, 2013a). Takšni podatki v veliko večji meri sledijo realnim dnevnim selitvenim tokovom prebivalstva in zato bolj odsevajo vsakodnevne življenjske prakse, ki so izhodišče preučevanega vpliva na volilno vedenje.

Obe vrsti podatkov o razdaljah med volišči smo primerjali z deležem prejetih glasov. Iskali smo morebitno statistično pomembno negativno korelacijo, ki bi bila močan argument za potrditev teze o vplivu učinka poznanstva in sosedstva. Za preverjanje korelacije med posameznimi pari spremenljivk smo izbrali Pearsonov koeficient korelacije. Ta je za potrebe izvedene analize najprimernejši, saj je posebej namenjen številskim (intervalnim ali razmernostnim) spremenljivkam in poleg statistične pomembnosti korelacije kaže tudi jakost povezanosti in njeno smer (pozitivno ali negativno).

Pred izračunom koeficienta je bilo potrebno preveriti pogoje za izvedbo izračuna normalno porazdelitev spremenljivke, linearno povezanost in homogenost varianc. Pri upoštevanju evklidske razdalje je bilo potrebno opraviti selekcioniranje podatkov (izločitev enot, ki so najbolj odstopale) ali transformacijo spremenljivke (izračun kvadratnega korena podatkov), da je bilo zadoščeno pogojem. Pri tem je bilo treba podatke enega kandidata izločiti, saj je bil delež volišč, na katerih ni prejel niti enega glasu, prevelik. Ob vključitvi stroškovne razdalje je prišlo do težave, saj je bilo nemogoče doseči pogoj normalne razporeditve spremenljivke na ravni testa Kolmogorov-Smirnov. Rezultate omenjenega testa je bilo treba zanemariti in izhajati iz zadovoljive mere normalnosti porazdelitve, ki se je izražala na razsevnih, Q-Q in Boxplot grafikonih razporeditve posameznih spremenljivk.

Zadnji del analize predstavlja kartografski prikaz, ki daje boljši vpogled v prostorsko razporeditev prejetih glasov posameznega kandidata. Za optimalno preglednost smo izračunali indeks deleža prejete podpore - razmerje med deležem podpore na kandidatovem domačem volišču in skupnim deležem podpore na območju VO Tolmin (vrednosti, večje od ena, predstavljajo nadpovprečen izid in obratno). Poleg iskanja vzorcev učinka poznanstva in sosedstva so nam kartografski prikazi omogočili analizo posebnosti v razporeditvi podpore, ki nakazuje lokalne posebnosti volilnega vedenja. Podatki o posameznih kandidatih (̌̌ivljenjepis, delovno mesto, družbeni položaj itd.) so nam pomagali razjasniti zapleten pojem volilnega vedenja, ki izhaja iz širokega spektra najrazličnejših dejavnikov.

\section{REZULTATI}

\section{I Statistična analiza rezultatov volitev}

$\mathrm{V}$ prvi fazi analize učinka poznanstva in sosedstva na volilno vedenje smo deleže prejete podpore na domačem volišču primerjali s prejeto podporo v VO. Pričakovano je vseh 12 kandidatov beležilo višjo podporo na domačem volišču. Največje razlike so se pokazale na voliščih z majhnim številom volilnih upravičencev, saj gre za podeželska naselja, kjer so poznanstva močnejša, prebivalstvo pa načeloma složnejše pri svojih odločitvah (Gimpel, 2008). 
Slika 3: Primerjava prejete podpore na domačih voliščih kandidatov in na območju celotnega VO Figure 3: Comparison of received support in candidate's domestic polling station with overall support in the electoral district

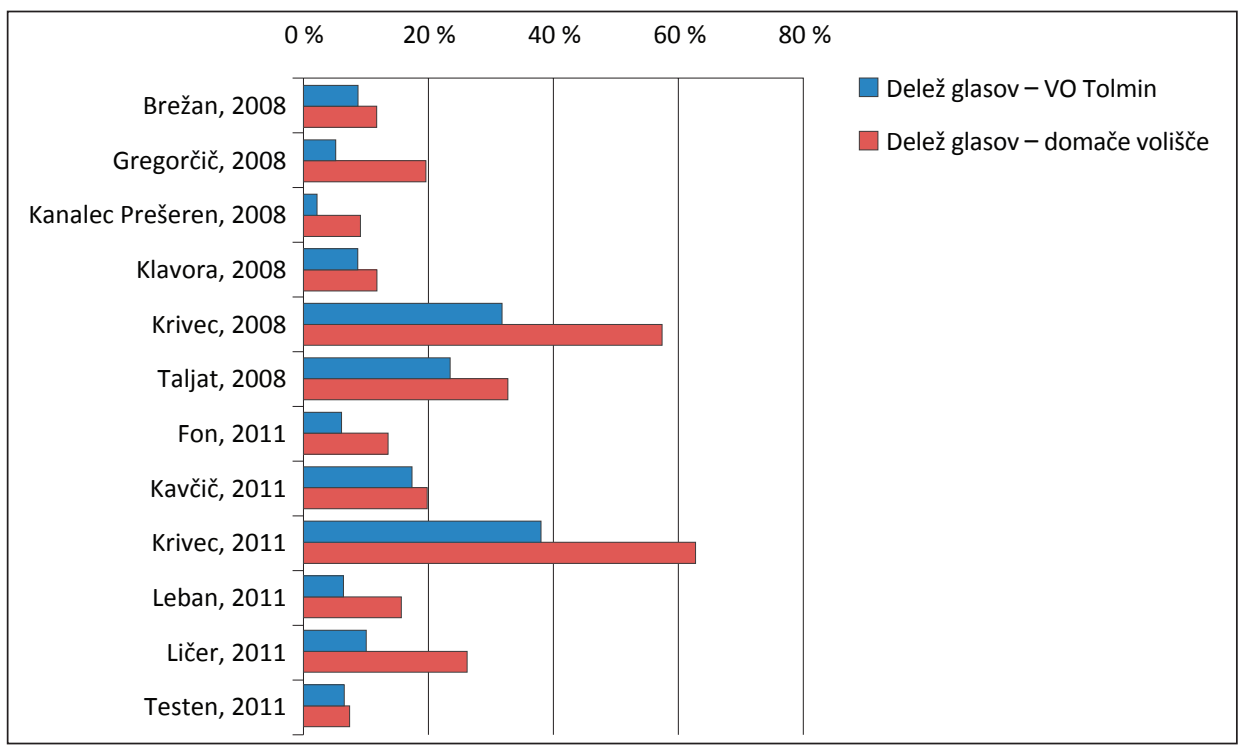

Vir/Source: DVK-RS, 2013

Drugi korak je vključeval primerjavo rezultatov glede na izvor kandidatov. Razlike med kandidati s stalnim bivališčem $\mathrm{v}$ mestih in tistimi, ki prihajajo s podeželja, niso bile velike. Pri razmerju med deležem glasov na domačem območju (določen z že obrazloženo delitvijo na mestna in podeželska območja) in skupnim deležem je bil količnik pri kandidatih iz mestnih območij celo višji $(1,28: 1,16)$. Večja razlika se je pokazala pri primerjavi skupne podpore s podporo na domačem volišču. Tu je razmerje v prid domačih volišč kandidatov s podeželskih območij naraslo na 2,26, medtem ko so bila volišča v mestih združena in je vrednost ostala na 1,28. Na tej stopnji je bilo mogoče predpostavko o močnejšem učinku poznanstva in sosedstva pri kandidatih s podeželja pogojno potrditi. 
Preglednica 2: Primerjava razmerja prejete podpore na mestnih in podeželskih območjih Table 2: Comparison of received support ratio between urban and rural areas

\begin{tabular}{|l|l|c|c|}
\hline Podatki o kandidatu & \multicolumn{2}{c|}{ Razmerje deležev glasov } \\
\hline Ime kandidata (stranka) & Domače območje & $\begin{array}{c}\text { Domače območje: } \\
\text { volilni okraj }\end{array}$ & $\begin{array}{c}\text { Domače volišče: } \\
\text { volilni okraj }\end{array}$ \\
\hline Danijel Krivec (SDS) & Bovec - podeželsko & 1,26 & 1,64 \\
\hline Anica Kanalec Prešeren (LDS) & Tolmin - podeželsko & 0,99 & 3,77 \\
\hline Uroš Brežan (SLS) & Tolmin - podeželsko & 1,34 & 1,32 \\
\hline Pavel Gregorčič (Zares) & Kobarid - podeželsko & 1,01 & 3,6 \\
\hline Simon Leban (DeSUS) & Dolina Idrijce & 1,35 & 2,42 \\
\hline Robert Kavčič (PS) & Kobarid - podeželsko & 0,76 & 1,13 \\
\hline Franc Ličer (SD) & Dolina Idrijce & 1,06 & 2,52 \\
\hline Danijel Krivec (SDS) & Bovec -- podeželsko & 1,26 & 1,81 \\
\hline Metod Fon (SLS) & Tolmin - podeželsko & 1,45 & 2,15 \\
\hline Povprečno razmerje - PODEŽELSKA OBMOČJA & $\mathbf{1 , 1 6}$ & $\mathbf{2 , 2 6}$ \\
\hline Ciril Testen (NSi) & Tolmin - mestno & 1,15 & 1,15 \\
\hline Vasja Klavora (DeSUS) & Bovec - mestno & 1,32 & 1,32 \\
\hline Dragica Rejec Taljat (SD) & Tolmin - mestno & 1,37 & 1,37 \\
\hline Povprečno razmerje - MESTNA OBMOČJA & $\mathbf{1 , 2 8}$ & $\mathbf{1 , 2 8}$ \\
\hline Povprečno razmerje - SKUPAJ & & $\mathbf{1 , 1 9}$ & $\mathbf{2 , 0 2}$ \\
\hline
\end{tabular}

Vir/Source: DVK-RS, 2013

Povezanost med deležem podpore in oddaljenostjo od domačega volišča je v dosedanjih raziskavah učinka poznanstva in sosedstva tujih strokovnjakov največkrat navedena kot relevanten znanstveni kazalec jakosti vpliva na volilno vedenje (Gimpel, 2008). Ob upoštevanju evklidske razdalje je Pearsonov koeficient v sedmih primerih (64 \% vseh obravnavanih) pokazal statistično pomembno negativno korelacijo, ki je bila pri petih kandidatih nizke jakosti, pri dveh pa celo srednje. Z zamenjavo evklidske s stroškovno razdaljo, ki smo ji pripisali večjo reprezentativnost dejanskega stanja, se je statistično pomembna negativna korelacija potrdila v petih primerih (46\% vseh obravnavanih). Poleg dejstva, da se je delež dokazanih korelacij zmanjšal, je pomembno dodati, da je bil rezultat v $82 \%$ primerov enak kot pri evklidski razdalji (preglednica 3), kar daje prvotnemu izračunu, kjer so vsi pogoji za izračun koeficienta izpolnjeni, dodatno težo. 
Preglednica 3: Pearsonov koeficient korelacije med deležem glasov in razdaljo od domačega volišča kandidata

Table 3: Pearson correlation coefficient between received support and distance from the candidates'local poll

\begin{tabular}{|c|c|c|c|c|c|c|}
\hline \multirow[b]{2}{*}{$\begin{array}{l}\text { Kandidat, leto } \\
\text { volitev }\end{array}$} & \multicolumn{3}{|c|}{ Korelacija podpore z evklidsko razdaljo } & \multicolumn{3}{|c|}{$\begin{array}{l}\text { Korelacija podpore s stroškovno } \\
\text { razdaljo }\end{array}$} \\
\hline & $\begin{array}{c}\text { Stat. } \\
\text { pomembnost } \\
\text { korelacije } \\
(\text { Sig. }<0,05) \\
\end{array}$ & $\begin{array}{c}\text { Vrednost } \\
\text { Pearsonovega } \\
\text { koeficienta }\end{array}$ & $\begin{array}{c}\text { Smer in } \\
\text { jakost } \\
\text { korelacije }\end{array}$ & $\begin{array}{c}\text { Stat. } \\
\text { pomembnost } \\
\text { korelacije } \\
(\text { Sig. }<0,05)\end{array}$ & $\begin{array}{c}\text { Vrednost } \\
\text { Pearsonovega } \\
\text { koeficienta }\end{array}$ & $\begin{array}{c}\text { Smer in } \\
\text { jakost } \\
\text { korelacije }\end{array}$ \\
\hline Brežan, 2008 & 0,01 & $-0,29$ & $\begin{array}{c}\text { nizka } \\
\text { negativna }\end{array}$ & 0,72 & 1 & $\begin{array}{c}\text { ni } \\
\text { korelacije }\end{array}$ \\
\hline Gregorčič, 2008 & 0,00 & $-0,31$ & $\begin{array}{c}\text { nizka } \\
\text { negativna }\end{array}$ & 0,03 & $-0,24$ & $\begin{array}{c}\text { nizka } \\
\text { negativna }\end{array}$ \\
\hline Klavora, 2008 & 0,02 & 0,26 & $\begin{array}{c}\text { nizka } \\
\text { pozitivna }\end{array}$ & 0,04 & 0,22 & $\begin{array}{c}\text { nizka } \\
\text { pozitivna }\end{array}$ \\
\hline Krivec, 2008 & 0,00 & $-0,58$ & $\begin{array}{c}\text { srednja } \\
\text { negativna }\end{array}$ & 0,00 & $-0,47$ & $\begin{array}{c}\text { srednja } \\
\text { negativna }\end{array}$ \\
\hline Taljat, 2008 & 0,69 & l & $\begin{array}{c}\text { ni } \\
\text { korelacije }\end{array}$ & 0,10 & l & $\begin{array}{c}\text { ni } \\
\text { korelacije }\end{array}$ \\
\hline Fon, 2011 & 0,01 & $-0,28$ & $\begin{array}{c}\text { nizka } \\
\text { negativna }\end{array}$ & 0,03 & $-0,24$ & $\begin{array}{c}\text { nizka } \\
\text { negativna }\end{array}$ \\
\hline Kavčič, 2011 & 0,57 & l & $\begin{array}{c}\mathrm{ni} \\
\text { korelacije }\end{array}$ & 0,20 & / & $\begin{array}{c}\mathrm{ni} \\
\text { korelacije }\end{array}$ \\
\hline Krivec, 2011 & 0,00 & $-0,54$ & $\begin{array}{c}\text { srednja } \\
\text { negativna }\end{array}$ & 0,00 & $-0,42$ & $\begin{array}{c}\text { srednja } \\
\text { negativna }\end{array}$ \\
\hline Leban, 2011 & 0,33 & / & $\begin{array}{c}\text { ni } \\
\text { korelacije }\end{array}$ & 0,36 & / & $\begin{array}{c}\text { ni } \\
\text { korelacije }\end{array}$ \\
\hline Ličer, 2011 & 0,03 & $-0,23$ & $\begin{array}{c}\text { nizka } \\
\text { negativna }\end{array}$ & 0,42 & / & $\begin{array}{c}\mathrm{ni} \\
\text { korelacije }\end{array}$ \\
\hline Testen, 2011 & 0,04 & $-0,23$ & $\begin{array}{c}\text { nizka } \\
\text { negativna }\end{array}$ & 0,01 & $-0,27$ & $\begin{array}{c}\text { nizka } \\
\text { negativna }\end{array}$ \\
\hline
\end{tabular}

\subsection{Kartografski prikaz indeksa deležev podpore kandidatov}

Pri iskanju vzorcev prostorske razporeditve volilne podpore smo uporabili kartografski prikaz indeksa deležev podpore, in sicer primerjavo vrednosti indeksa na posameznih voliščih z njihovo oddaljenostjo od kandidatovega domačega volišča. Posamezne primere specifičnih prostorskih razporeditev smo obrazložili podrobneje. 
Slika 4: Indeks prejete podpore kandidata Danijela Krivca na volitvah 2008 in 2011

Figure 4: Index of candidate's Danijel Krivec received support in the elections of 2008 and 2011

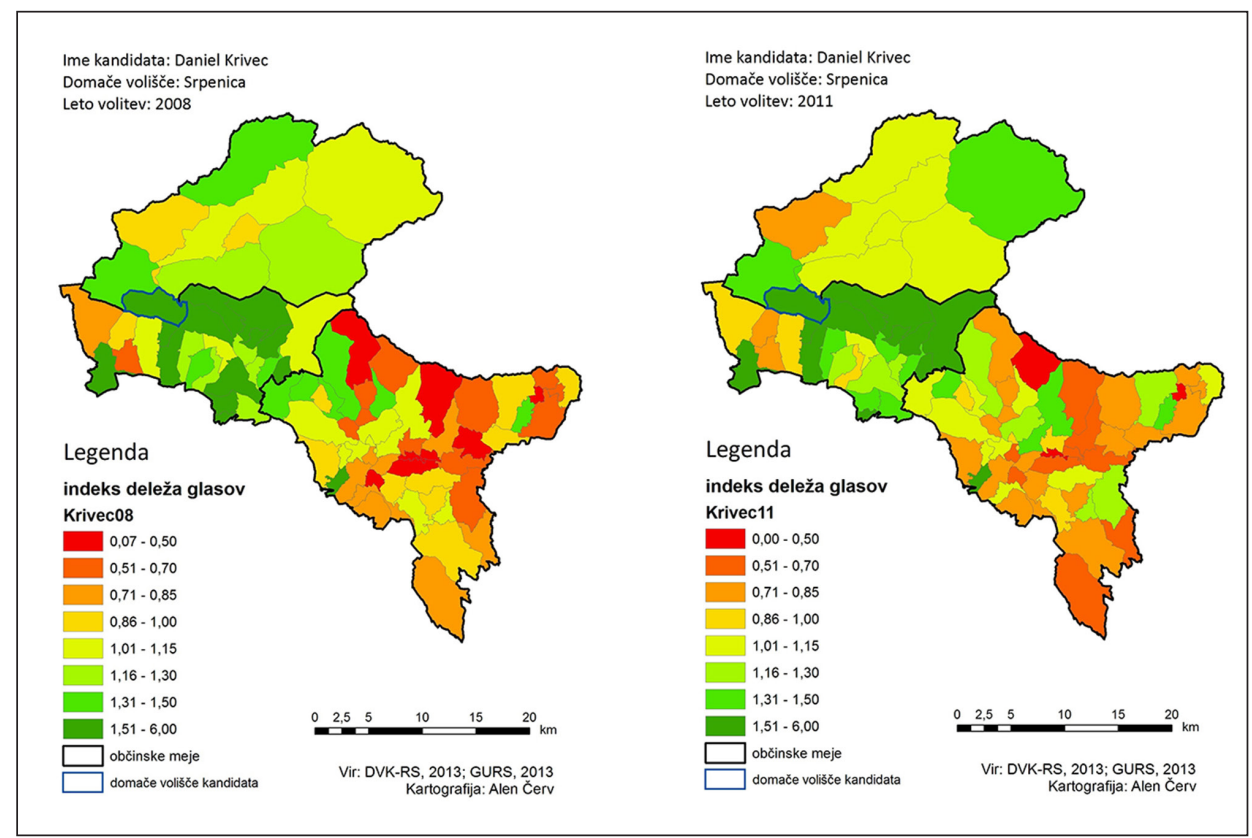

Vira/Sources: DVK-RS, 2013; GURS, $2013 b$

Kandidat D. Krivec je kandidiral tako leta 2008 kot 2011 (slika 4). V obeh primerih je Pearsonov koeficient določil negativno korelacijo srednje jakosti. Gre za jasen kazalec učinka poznanstva in sosedstva, saj podpora enakomerno pada $\mathrm{z}$ oddaljenostjo. Poleg tega je opaziti močno podporo v smeri najnižje stroškovne razdalje (po dolini reke Soče proti severozahodu in jugovzhodu). V kolikor bi bila večina primerov takšna, bi bila teza o splošnem vplivu učinka poznanstva in sosedstva na volilno vedenje brez težav potrjena. Omeniti velja še opazno razliko v podpori med občinama Tolmin (jugovzhodni del VO) in Kobarid (osrednji del), ki se ji bomo posvetili pri naslednjem primeru. 
Slika 5: Indeks prejete podpore kandidatov Metoda Fona in Franca Ličerja na volitvah 2011 Figure 5: Index of candidates' Metod Fon and Franc Ličer received support in the election of 2011

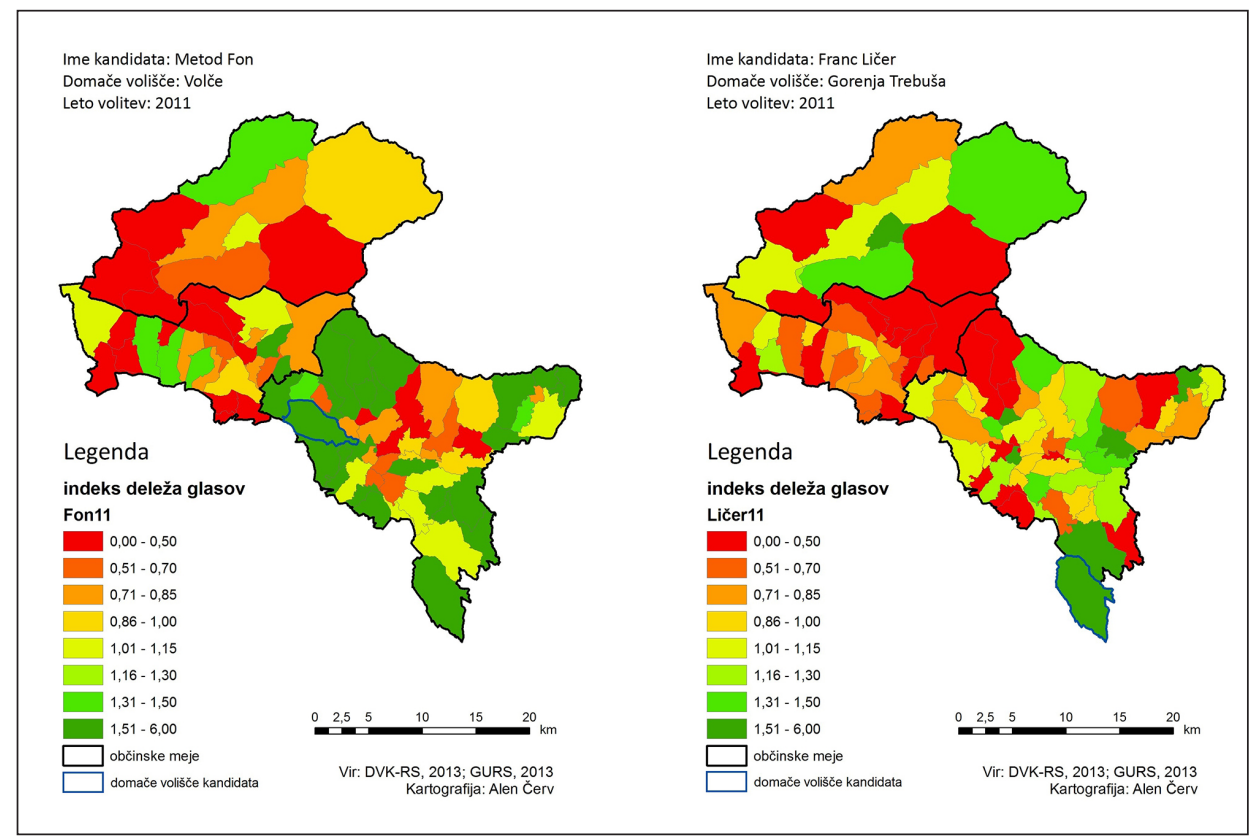

Vira/Sources: DVK-RS, 2013; GURS, $2013 b$

Kandidata M. Fon in F. Ličer prihajata iz tolminskega podeželskega zaledja (slika 5). Pri obeh smo ugotovili negativno korelacijo nizke jakosti, za nas pa sta primera zanimiva predvsem zaradi izrazite razlike v podpori med občinama Tolmin in Kobarid. Oba kandidata beležita daleč najslabše rezultate na območju občine Kobarid, kar bi lahko pripisali medsosedskemu rivalstvu in strahu pred favoriziranjem lastne občine v primeru izvolitve. Gre za obliko učinka soseščine, pri katerem načela okolice vplivajo na odločanje posameznika na zavestni ali podzavestni ravni (Jones, Woods, 2004). 
Slika 6: Indeks prejete podpore kandidatov Simona Lebana in Cirila Testena na volitvah 2011 Figure 6: Index of candidates' Simon Leban and Ciril Testen received support in the election of 2011

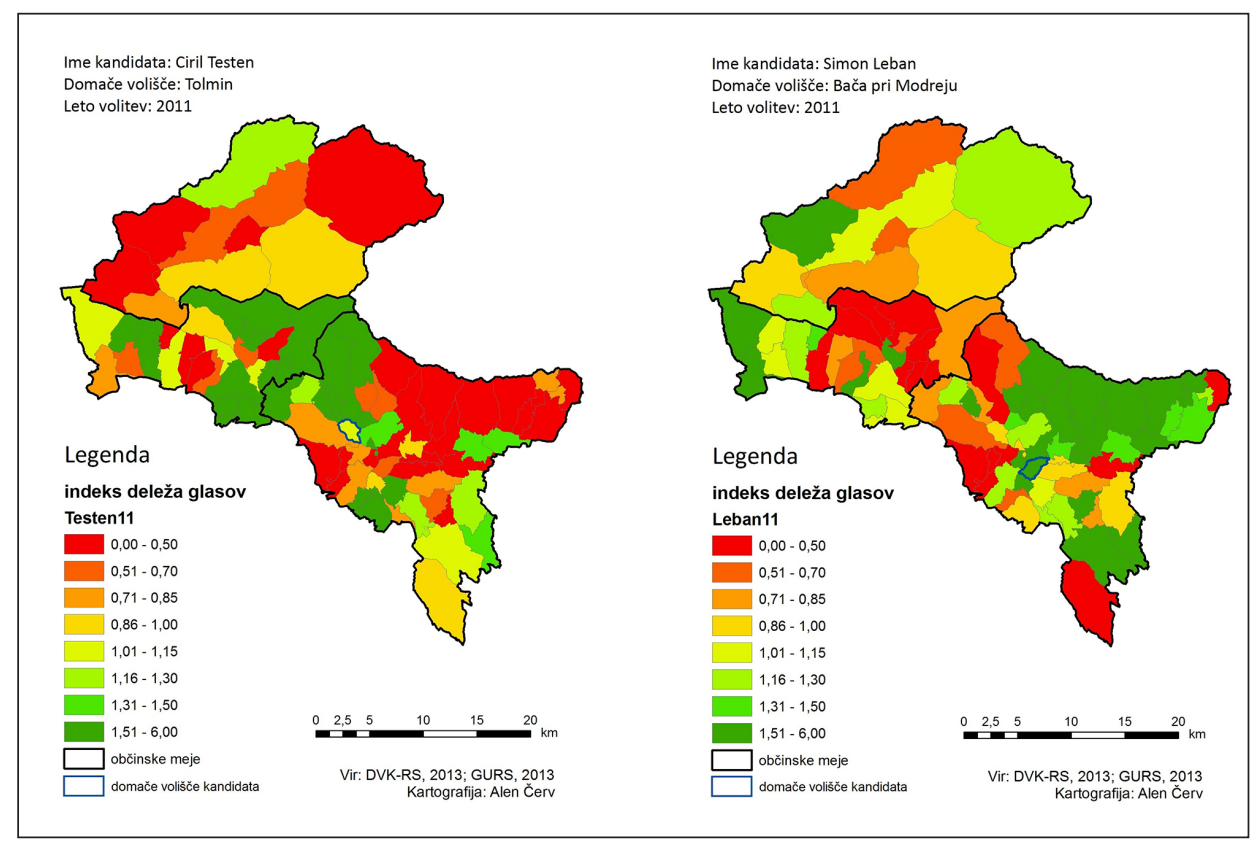

Vira/Sources: DVK-RS, 2013; GURS, $2013 b$

Rezultati naslednjih dveh kandidatov nam prikazujejo relativnost pomena evklidske razdalje (slika 6). Na prvi pogled sta si volišči Tolmin (kandidat C. Testen) in Bača pri Modreju (kandidat S. Leban) prostorsko zelo blizu, vendar ju funkcijska razvodnica uvršča v različni gravitacijski zaledji. Izoblikovanost površja je odločilno vplivala na dnevne migracije, število socialnih stikov, mentaliteto in občutek pripadnosti prebivalstva obeh območij. Medtem ko se območje Tolmina odpira po dolini Soče navzgor (smer severozahod), leži Bača pri Modreju na sotočju rek Idrijce (jugovzhodni del VO) in Bače ter spada v območje Baške grape (vzhodni del VO) (Červ, 2014). Prostorska razporeditev podpore z vidika učinka poznanstva in sosedstva jasno prikazuje razdeljenost območja in posledično tudi prebivalstva. Omeniti velja, da je bila izračunana korelacija v obeh primerih zelo šibka, kar dokazuje, da so statistični podatki pri prostorskih problemih samo ena izmed metod, ki pa jo je potrebno dopolniti s kartografsko analizo dejanskega stanja v prostoru. 
Slika 7: Indeks prejete podpore kandidatov Uroša Brežana in Vasja Klavore na volitvah 2008 Figure 7: Index of candidates' Uroš Brežan and Vasja Klavora received support in the election of 2008

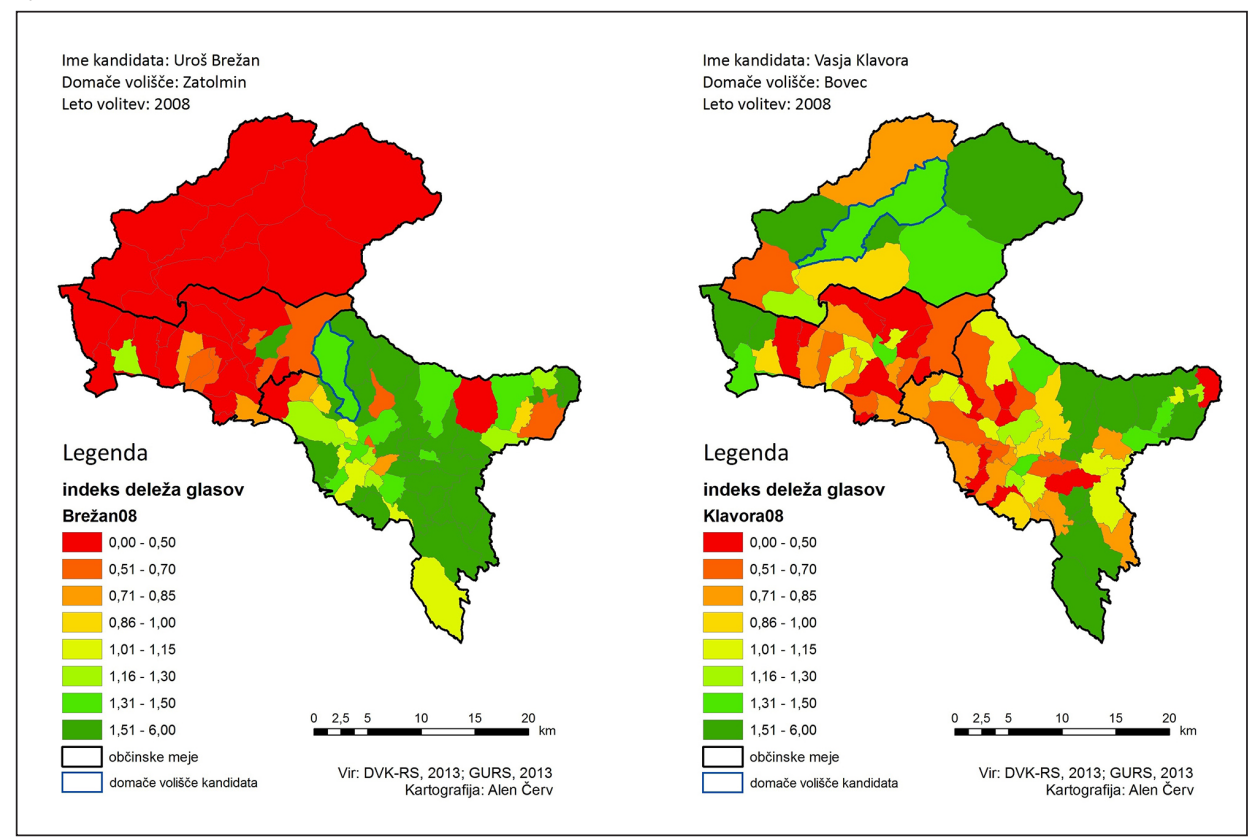

Vira/Sources: DVK-RS, 2013; GURS, $2013 b$

Smiselno je navesti še dva primera sekundarnih vplivov na volilno vedenje (slika 7). Pri kandidatu U. Brežanu je bilo opaziti diametralno nasprotje pri podpori na območju občine Tolmin v primerjavi s preostalima občinama. Tokrat ne gre (le) za medsosedsko rivalstvo, pač pa za vpliv funkcije kandidata, ki je bil v času volitev župan občine Tolmin. Združljivost poslanske in županske funkcije, ki jo je slovenska zakonodaja za razliko od večine razvitih držav dovoljevala do leta 2012, je botrovala (upravičenemu) strahu pred favoriziranjem domače občine v primeru preboja v Državni zbor.

Preteklo poklicno udejstvovanje (kirurg, pisatelj ipd.) in aktualna funkcija (podpredsednik Državnega zbora) sta pomembno vplivala tudi na rezultate kandidata V. Klavore, pri katerih smo ugotovili celo pozitivno korelacijo, kar je v popolnem nasprotju s pričakovanji. Gre za vpliv prepoznavnosti in splošne priljubljenosti, ki deluje nasprotno od učinka poznanstva in sosedstva (Jones, Woods, 2004). Primera dokazujeta kompleksnost in lokalne posebnosti volilnega vedenja, ki kljub odvisnosti od poznavanja kandidata ne izhajajo vedno samo iz prostorske bližine. Slednja ima torej na volilno vedenje omejen vpliv. 


\section{SKLEP}

Statistične in kartografske analize so v kombinaciji s teoretičnimi izhodišči o učinku poznanstva in sosedstva dokazale kompleksnost volilnega vedenja. Kljub temu je mogoče iz rezultatov izpeljati številne zaključke, ki bodo v pomoč nadaljnjim analizam. Najprej je potrebno poudariti, da pridobljenih rezultatov ne moremo posplošiti na državno ali katerokoli drugo širšo raven, saj smo analize izvedli na specifičnem, obrobnem območju, ki ima edinstven značaj in nikakor ne more služiti posploševanju. Pri tolminskem volilnem okraju gre namreč za relativno zaprto in socialno homogeno območje z visoko stopnjo medsebojnega poznavanja (Červ, 2014).

Za preučevano območje je mogoče potrditi predpostavko, da podpora kandidatu ne upada enakomerno z oddaljevanjem od domačega volišča, saj na odločitev volilnega telesa vpliva širši splet dejavnikov. Učinek poznanstva in sosedstva na preučevanem območju je močnejši na podeželskih in šibkejši na mestnih območjih. Pri tem je potrebno omeniti, da ima največje naselje v tolminskem volilnem okraju manj kot 5000 prebivalcev in o mestnih središčih z vidika števila stalnega prebivalstva niti ni mogoče govoriti.

Volilna praksa je lokalno specifičen pojav, ki je odvisen od pestrega nabora sekundarnih dejavnikov. Regionalne in lokalne značilnosti, medsosedska rivalstva in vpliv funkcije kandidatov so le nekateri izmed vzrokov za odklone v volilnem vedenju. Pri dojemanju slednjih je poleg geomorfoloških značilnosti potrebno upoštevati tudi administrativne, zgodovinske in gospodarske ločnice v prostoru.

Delovne hipoteze o pomembnem vplivu učinka poznanstva in sosedstva na volilno vedenje na osnovi opravljenih analiz ni mogoče zanesljivo potrditi. Čeprav je bila v 64 \% primerov statistično dokazana negativna korelacija med deležem podpore in oddaljenostjo od domačega volišča kandidata, se je potrebno zavedati, da je bila jakost korelacije praviloma nizka. Prav tako je delež tovrstnih primerov po prilagoditvi podatkov na realnejšo raven (zamenjava evklidske razdalje s stroškovno in geometričnih središč s središči gostote stavb) upadel pod polovico. Potrditi pa je mogoče, da se učinek poznanstva in sosedstva kaže v posameznih primerih in bi bilo smiselno opraviti nadaljnje analize tega pojava na širši ravni. Na podlagi navedenih izkušenj predlagamo obtežitev izračunanih razdalj na osnovi občinskih in drugih administrativnih meja, ki vplivajo na razlike v volilnem vedenju prebivalstva. Prav tako bi bilo smiselno $\mathrm{z}$ anketiranjem in intervjuvanjem prebivalstva pridobiti globlji vpogled v vzorce odločanja in dejavnike, ki nanje vplivajo. Poleg informativne in znanstvene vrednosti je smisel prispevka tudi spodbuda za nadaljnje raziskave, s katerimi bi lahko izluščili prednosti in slabosti sedanjega volilnega sistema in pomagali soustvarjati morebitne pozitivne spremembe $\mathrm{v}$ prihodnosti.

\section{Viri in literatura}

Červ, A., 2014. Vpliv učinka poznanstva in sosedstva na volilno vedenje. Analiza rezultatov volitev v Državni zbor Republike Slovenije 2008 in 2011 v volilnem okraju Tolmin. Zaključna seminarska naloga. Ljubljana. Filozofska fakulteta, Oddelek za geografijo, 53 str. 
Državna volilna komisija (DVK-RS), 2013. Izidi volitev v Državni zbor Republike Slovenije 2008 in 2011, prikaz po voliščih (interno gradivo).

Državni zbor RS, 2011. Volitve in volilni sistem. URL: http://www.dz-rs.si/wps/portal/ Home/PoliticniSistem/VolitveInVolilniSistem (Citirano 2. 11. 2013).

Geodetska uprava Republike Slovenije (GURS), 2013a. Digitalni model nadmorskih višin Slovenije v ločljivosti 100 m. Ljubljana, Ministrstvo za okolje in prostor, Geodetska uprava Republike Slovenije.

Geodetska uprava Republike Slovenije (GURS), 2013b. Državnozborska volišča in volilni okraji, stanje na dan 1. 12. 2008 in 1. 12. 2011. Ljubljana, Ministrstvo za okolje in prostor, Geodetska uprava Republike Slovenije.

Geodetska uprava Republike Slovenije (GURS), 2013c. Kataster stavb. Ljubljana, Ministrstvo za okolje in prostor, Geodetska uprava Republike Slovenije.

Gimpel, J. G., 2008. Distance-decay in the political geography of friends-and-neighbors voting. Political geography, 27, 2, str. 231-252. DOI: 10.1016/j.polgeo.2007.10.005

Johnston, R. J., 1974. Local effects in voting in a local election. Annals of the Association of American geographers, 64, 3, str. 418-429. DOI: 10.1111/j.1467-8306.1974. tb00990.x

Jones, M., Woods, M., 2004. An introduction to political geography: space, place and politics. London, Routledge, 202 str.

Key, V. O., 1949. Southern politics in state and nation. Knoxville, A. A. Knopf, 675 str.

Luthar, B., 1993. Pledoaje za raziskovanje politične izbire kot stilistične izbire. V: Adam, F. (ur.). Volitve in politika po slovensko. Ljubljana, Znanstveno in publicistično središče, str. 113-138.

Pečjak, V., 1995. Politična psihologija. Ljubljana, samozaložba, 307 str.

Rogelj, B., 2012. Ureditev volilnih enot v državnozborskem volilnem sistemu. Dela, 37 , str. 107-128. DOI: http://dx.doi.org/10.4312/dela.37.6.107-128

Simiyu, R., 2010. Politics of residency, friends and neighbors effect, and voting patterns in Kwanza constituency, Kenya, 1988-2000. African geographical review, 29, 1, str. 37-61.

Taylor, P. J., Johnston, R. J., 1979. Geography of elections. Harmondsworth, Penguin, $528 \mathrm{str}$.

Tiran, J., 2010. Tip naselbinskega območja kot dejavnik volilnega vedenja. Analiza volitev v Državni zbor 1996-2008. Diplomsko delo. Ljubljana, Filozofska fakulteta, Oddelek za geografijo, 101 str. URL: http://geo.ff.uni-lj.si/pisnadela/pdfs/dipl_201003_ jernej_tiran.pdf (Citirano 11. 10. 2013).

Zakon o spremembah in dopolnitvah Zakona o volitvah v državni zbor (ZVDZ), 2006. Uradni list RS, št. 78/06. URL: http://www.uradni-list.si/1/index?edition=2006109\#!/ Uradni-list-RS-st-109-2006-z-dne-23-10-2006 (Citirano 21. 10. 2013).

Zakon o volitvah v državni zbor (ZVDZ), 1992. Uradni list RS, št. 44/92. URL: http://www.uradni-list.si/1/content?id=64014\&part=u\&highlight=zakon+o+volitvah+v+dr\%25C5\%25BEavni+zbor\#!/Zakon-o-volitvah-v-drzavni-zbor (Citirano 21. 10. 2013). 


\section{THE IMPACT OF FRIENDS-AND-NEIGHBOURS EFFECT ON ELECTORAL BEHAVIOUR IN THE TOLMIN ELECTORAL DISTRICT}

\section{Summary}

The friends-and-neighbours effect refers to the tendency for voters to support candidates from their home areas regardless of party affiliation, apparently because such candidates are better known to them, have a better grasp of local issues, share in local interests and would therefore be more motivated to address local problems if elected (Simiyu, 2010). The impact of described effect was verified by analysis of the results of National Assembly elections in 2008 and 2011 in Tolmin electoral district - one of 88 electoral districts in Slovenia that give 88 members of National Assembly.

We figured out that proportional representation system of elections in Slovenia is focused on the selection of political parties and not local candidates. However, analysis of the results showed significant support for local candidates that could be caused by friends-and-neighbours effect. Due to the complexity of electoral behaviour, which could not be explained solely with statistical parameters, one has to be really careful in interpreting the results.

More than half of analysed results of candidates corresponded to the pattern of friends-and-neighbours effect, but correlations between number of votes and the distance from the candidate's home polling station were weak and they got even weaker when we optimized spatial data. Cartographic presentations also showed drop of support with increasing distance from the domestic polls, but there were also some cases demonstrating the effect of other influences on electoral behaviour. In one case, the connection was even reversed. That was the reason for consideration about specific local factors of electoral behaviour.

First of them is social homogeneity of the area that is really closed and well internally connected. Connections between people are strong and they have a common gravitation centre, but the strength of connections is not related with distance so much. Electorate is familiar (read: knows) with all the candidates and sometimes connections have even negative impacts due to some bad experiences from the past. Next factor is career position of candidates in social life. The best example is Mr. Brežan, who was mayor of the Tolmin municipality at the time of 2008 elections. It was a specific practice in Slovenia, where members of National Assembly were allowed to perform the role of the mayor as well. Among the candidates were also doctors, lawyers and other public servants whose function has affected their popularity among voters. Another local factor is the neighbourhood effect. It occurred as neighbourhood rivalry between Tolmin and Kobarid areas. Cartographic presentations showed significant difference in support between both municipalities in almost all the cases.

After completion of the analysis we can conclude that friends-and-neighbours effect is stronger in rural than in urban areas. It was also confirmed that electoral support does not drop evenly with the distance from domestic polls. Another conclusion is locally specific electoral behaviour with a lot of factors that affect the decision of voters in a particular area. That is the reason we cannot generalize our results to the entire territory of Slovenia. 
The main hypothesis of the paper was disproved. It means that results did not confirm significant impact of friends-and-neighbours effect on electoral behaviour in the entire area of Tolmin electoral district. There were just $46 \%$ of cases with confirmed statistically significant correlation, which is not sufficient to generalize the impact to the entire area of electoral district. However, the impact was evident in several cases and this could be a proper reason for further research.

(Translated by the author) 